\title{
PETROLEUM AS A SOURCE OF EMERGENCY POWER FOR WAR-SHIPS.
}

\author{
By N. B. Clark, Passed Assistant-Engineer, U. S. N.
}

A war-ship requires two different rates of speed, one, which for convenience of expression, may be called passage power, would be used on all ordinary occasions when steaming from port to port; and the other, emergency power, required for chasing an enemy or escaping from a superior foree, when a high rate of speed will be necessary.

The requirements of a cruising war-ship and a commercial vessel making regular passages from port to port are entirely different. The passenger or fast freight steamer needs sustained high speed to enable her to make trips in the shortest time possible and with the utmost economy of fuel in order to pay a profit to her owners; while the warship does not need sustained high speed, but requires a still higher rate of speed to be used for only a few hours at a time in an emergency, it being admissible to attain this extreme high speed at an extravagant cost of fuel, as economy of fuel can only be attained by great weight of machinery, involving increased displacement.

It was the experience of officers who served on the vessels blockading the southern coast that if a blockade-runner was sighted early in the day her capture was almost a certainty notwithstanding the assumed superiority in speed of that class of vessels; but if the vessel was not sighted in time to admit of her eapture before night, darkness frequently enabled her to elude her pursuers, even though they possessed superior spced.

As darkness favors the weak in eluding pursuit, commerce destroyers should be provided with high emergency power to enable them to capture their prizes while daylight lasts.

The passage power of a war-ship should be so designed as to be capable of being used with great economy of fuel, enabling the vessel to steam great distances, and to keep the sea for lengthened periods of time; while on the other hand, to avoid excessive weight of machinery, economy of fuel would be a matter of secondary consideration when using the emergency power, which would be but rarely called into action, and then for only a short period of time, and therefore would not warrant the encumbrance of a great weight of machinery.

The passage power of a war-ship may be sufficient to drive the ship 
nine or ten knots per hour, while her emergency power should be equal to the attainment of donble that speed. This would require the emergency power to approximate to eight times the passage power.

Such enormous power cannot be attained in a vessel of ordinary size, burning solid fuel on grate bars with natural draught, designed for economy of fuel, unless the entire hull of the ship is filled with boilers, absorbing the greater part of the displacement by the weight of the engines, boilers and fucl, thereby depriving the vessel of offensive and defensive power.

It has been proposed to construct such vessels, in which all other desirable qualities would be sacrificed to extreme high speed, but the propriety of such a course may well be questioned. High speed alone, without a due complement of defensive and offensive power, would simply cnable a naval commander to chase down an enemy which he dare not fight, a feat by which he would gain only negative renown.

Although it is impracticable to construct a vessel of ordinary dimensions, combining extreme high speed with due defensive and offensive qualities, with motive power derived from the combustion of solid fuel or grate bars in ordinary boilers with natural draught, yet, with liquid fuel, such a speed can be developed in a vessel of very moderate displacement.

In boilers for consuming solid fuel the steam generating power is measured by the area of the grate surface, and even when the draught is forced, the amount of heat produced from such fuel is much less than the heating surface will absorb, provided the heating surface is the maximum the boilers will contain.

Solid fuel is burned only from its surface by the erosive action of diluted oxygen, consequently the combustion of such fuel is slow and torpid compared with liquid fuel, which can be converted into a gas with rapidity and facility.

Ordinary marine boilers for consuming anthracite coal have from 20 to 25 square feet of heating surface to the square foot of grate, and such boiler's are found to give good results with solid fuel, as the heating surface is suffieient to absorb all the heat that can be generated from such fuel; but it is possible to construct tubular boilers for buming petroleum having 75 square feet of heating surface to the square foot of grate.

With such boilers having the liquid fuel sprayed into their furnaces by jets of superheated steam or hot air, the steam generating power 
wonld be measured by the largely increased extent of the heating surface, and not by the limited area of the grate, as the fuel could be consumed at a rate fully up to the capacity of the heating surface to absorb the heat generated by its combustion.

In a properly constructed furnace, petroleum can be burned entirely without smoke, the combustion being complete, and its practical calorific value has been proved to be fully equal to three times its weight of the best coal.

A. high authority on engineering subjects, Molesworth's Pocket-book, p. 460 , revised edition, gives the following account of the method of burning petroleum, as practiced in England, with its advantages as a fuel :

"No alteration of the ordinary furnace or grate is necessary. For burning oil the grate bars are covered with slabs, overlaid with fine cinders, and the ash-pit doors closed. The oil fell vertically, a jet of superheated steam met it, and turned it into vapor, which then took fire and was consumed in a perfect manner.

"The water evaporated amounted to 20.8 pounds per pound of oil consumed. The average result of several days' experiment was $19 \frac{1}{2}$ pounds of water evaporated per pound of oil.

"With the best Aberdare coal the same boiler evaporated $6 \frac{1}{2}$ pounds of water per pound of coal consumed. The advantages claimed for liquid fuel in seagoing vessels are :

"1st. A reduction of weight of fuel.

" $2 \mathrm{~d}$. A reduction of bulk of fuel.

" 3 d. A reduction of fire-room force in the porportion of 4 to 1 .

"4th. Prompt kindling of fires.

" 5 th. The fires can be extinguished instantaneously.

" 6 th. Capability of stowage in place of water ballast, by which it may be replaced as consumed, and great facility for taking in rapidly.

" 7 th. Its cleanliness, and freedom from ashes cinders, etc.

" 8 th. The absence of the loss of heat due to the frequent opening of furnace doors.

" 9 th. The ability to command a more intense fire, and management of temperature without forced draught.

"10th. Facility for perfect combustion and rapidity of raising: steam.

"11th. Freedom from smoke."

Mr. Henry F. Hayden, of Washington, D. C., has recently obtained 
several United States patents on furnaces for an improved method of buming hydrocarbons, in which the liquid foel is sprayed into the furnace by a jet of steam superheated to $1,200^{\circ}$ Falur., and having the air-supporting combustion heated to $800^{\circ}$ Fahr. By this method it is claimed petroleum will give a calorific value greater than the above estimate.

In order to show the merits of petroleum as a source of emergency power we will take for illustration the proposed 3,000-ton cruisers, in which it is understood 1,200 tons of the displacement is allotted to steam machinery and fuel, the weight of the machinery being 700 tons, and the coal 500 tons.

If the boilers of these ships were specially designed to burn petroleum as an emergency finel, their steam generating power could be doubled, while their weight could be decreased 150 tons.

The same boilers coukd also be used to consume anthracite coal with great economy when the ship was using her passage power.

If instead of carrying 500 tons of coal, the ship was equipped with 260 tons of coal, and 80 tons of petroleum stored in the cellular bottom, aggregating 340 tons, she would have her full complement of fuel, the equivalent of 500 tons of coal, thereby effecting a saving in weight of 160 tons.

If this aggregate weight of 310 tons, saved from boilers and fuel, was put into deflecting armor and heavy guns, in addition to the weights already allotted for that purpose, it would produce vessels of moderate size and cost, having a greater emergency speed than any existing commercial vessel, and having offensive and defensive powers equal to a heavy iron-clad. Such a ship would combine all the desirable qualities of a light, rapid cruiser, and a heavy coast-defence vessel.

The reason why petroleum has not been used as a fuel in the merchant marine is on account of its cost, and it is not likely that it will ever be able to compete successfully with its powerful rivals, anthracite and bituminous coal.

The objection to the use of petroleum in the vessels of the navy is its assumed dangerous character, but it should be remembered that the same objection could be urged against gunpowder, and was strongly urged against the introduction of steam, notwithstanding which both gunpowder and steam lave been introduced, and will be retained in spite of their dangerous character.

In regard to the dangerous qualities of petroleum it may be said, if 
its storage and use were surrounded by the same safeguards and precautions as those we observe in the storage and use of gunpowder, it would not be found any more dangerous. Besides it should not be forgotten that fighting, the purpose of a war-ship, cannot be made a safe business. The chief danger from petroleum arises from the emanation of an inflammable gas which is given off at all ordinary temperatures, but with refined petroleum this gas is scarcely appreciable in quantity when the fluid is kept at the temperature of sea water, which could be accomplished by storing it in the double bottom of the vessel, and danger from an accumulation of gas in the petroleum tanks could be avoided by providing them with appropriate ventilating pipes, leading overboard, above the water line.

While the cost of petroleum will bar its use as a fuel in the merchant marine, its introduction as an emergency fuel for the navy would be a measure of great economy. In the navy the neccessities of the service require a very large fire-room force, fully 33 per cent. of which may be denominated emergency men, whose services might be dispensed with except when the ship is using her full steam power.

With petroleum as a source of emergency power the services of these extra men could be dispensed with, and the cost of their pay, rations, etc., would far more than compensate for the difference between the cost of cual and petroleum, as the pay, rations, etc., of the emergency men would be continuous, while the extra cost of the emergency fuel would only have to be borne for short durations of time at long intervals.

One advantage to be derived from the use of petroleum as a source of emergency power is that it will enable us to retain anthracite coal as the standard fuel of our navy, otherwise we will be forced to use bituminous coal in order to compete in speed with the ships of other nations.

It is proposed to use anthracite coal as the source of the passage power, reserving the petroleum for emergencies, the same boilers serving for each, but of course the petroleum could be utilized for the lower rate of speed should necessity require it.

Numerous trials of single and twin serew ships of the British navy prove that twin screws utilize 11 per cent. more power in propelling the ship than single screws; this is no doubt due to the greater immersion of the effective area of the twin screws. The principal source of loss with the screw propeller is from skin friction, which is 
constant at all depths of immersion, while the propulsive efficiency increases with the depth of immersion. As twin screws give an increased efficiency of 11 per sent. over single screws, it is highly probable that triple screws would show a greater efficiency than twin screws, as, owing to the deeper immersion of the shafts, a less area of blade would give an equal propulsive efficiency, and if there was less area of blade there would be less loss from skin friction, and consequently a greater proportionate efficiency from the power applied.

The application of two or more serews would result, not only in a greater cconomy and efficiency of the power applied, than can be obtained from a single screw, lut also in greater safety to the vessel, as it is not probable that all the screws would be disabled at one time. It would also admit of a further decrease of spars and sails, which would be a great encumbrance to a vessel chasing a more lightly sparred adversary, who would not fail to run to windward.

In order to avoid unnecessary friction it would be desirable to disconnect a part of the machinery when using her lower rate of power. This could be accomplished by dividing the motive power of a twin screw ship between two vertical cylinders, direct acting, compound engines, one double cylinder compound engine being set forward of, and the other aft of a driving pinion on the crank shaft of each screw, with a disconnecting device to each engine. This arrangement would permit either or both compound engines to be used for driving the screw. When rumning with the passage power only one engine would be used to drive each screw, when using the emergency power both engines would be connected. This type and disposition of machinery would be a great safeguard against accidents.

According to the able and very valuable report of Passed $A$ ssistantEngineer John A. Tobin, U. S. Navy, published as House Executive Document 48 , of the Second Session of the 47 th Congress, the weight of the steam machinery of British merchant steamers is 480 pounds per indicated horse-power, and that of the vessels of the British Navy is 289 for the light steamer Iris and 360 pounds for other vessels; the weight of the steam machinery of the torpedo ram Polyphemas, having locomotive tubular boilers, is 180 pounds; and that of the two classes of light swift torpedo boats is 57.7 and 66.5 pounds per indicated horse-power.

This great reduction of weight is accomplished by the adoption of the locomotive tubular boiler, constructed of steel, furnishing steam of 
high pressure to engines constructed of the very best material, to secure great strength with lightness, designed for extreme high piston speed, whereby great power is transmitted by very light machinery, the light machinery developing the great power by its rapidity of movement.

If the same general plan of steam machinery, in a modified form, were adopted for cruising vessels as that applied in the construction of torpedo boats, engines capable of transmitting the proposed emergency power of 18 or 20 knots per hour could be constructed within the limits of weight allotted for that purpose.

As the torpedo boats referred to, having a displacement of less than 100 tons, have attained a speed of 22.4 knots per hour on the measured mile, the emergency speed proposed will not seem unreasonable for a vessel of 3,000 tons displacement to those familiar with the law of speed in relation to dimensions as enunciated by the late Mr. Froude.

Nor would it be neccessary to build vessels so large as 3,000 tons displacement in order to combine high speed with great defensive and offensive powers, for extremely useful vessels could be constructed on 1,500 or 2,000 tons displacement, and as a cruiser can only be in one place at a time, no matter how great her size, and as a small vessel upon the plan proposed would be as effective as a commerce destroyer as the largest, it would seem to be the best' policy to devote the small appropriations obtainable for the increase of the navy to the construction of a greater number of small ships, rather than to a less number of large ones.

Two such small swift cruisers of 2,000 tons displacement, armed with $10 \frac{1}{2}$ " pivot guns, mounted on vertical V shields, and with a proper complement of Hotchkiss revolving cannon, having an emergency speed of 18 or 20 knots, and provided with means of discharging rocket torpedoes, would be more than a match for an Inflexible or an Italia, as, owing to their small size and rapidity of movement, they would be very difficult to hit, either with shot or torpedo, while their unwieldy adversary would fall an easy victim to the latter weapon discharged from the two cruisers. The cost of construction and maintenance of one vessel of the Inflexible or Italia class will be found to be four times greater than that of two of the proposed cruisers of 2,000 tons displacement, while the fighting strength of the two latter combined, will be more efficient than that of one of the former. 